\title{
2.5. Rodzic w edukacji włączającej jako współuczestnik procesu
}

DOI: 10.47050/65591838.248-262

Beata Rola

W rozdziale przedstawione zostały warunki współpracy rodziców dzieci z niepełnosprawnościami ze szkołami. Autorka wskazuje przepisy prawne $w$ tym zakresie i bariery $w$ ich stosowaniu. Zwraca uwage na znaczenie pojęć "współpraca”, „partnerstwo" i "pomoc” - jako kryteriów sukcesu lub porażki we wzajemnych działaniach na rzecz dziecka. Wskazuje wyznaczniki kultury włączania, odwołując się do takich wyrażeń jak: „tolerancja”, „akceptacja”, „zrozumienie” i „odpowiedzialność”. Scharakteryzowane zostały postawy nauczycieli i rodziców, istotne w procesie zmiany, a także możliwe działania szkoły na rzecz rozwijania współpracy z rodzicami dzieci z niepełnosprawnością.

\section{Słowa kluczowe:}

\section{współpraca}

\section{partnerstwo}

kultura włączania

tolerancja

akceptacja 


\subsection{Parent as a participant of inclusive education process}

DOI: 10.47050/65591838.248-262

Beata Rola

The chapter presents the terms of cooperation between the school and the parents of children with disabilities. The author describes the law regulations and barriers to its implementation, introduce the terms cooperation, partnership and assistance as well as criteria for success or failure in mutual actions for the child. The article discusses also the concept of inclusion culture using words such as: tolerance, acceptance, understanding and responsibility, the attitudes of teachers and parents important in the process of change, and attempt to define the supporting activities of the school for cooperation with parents of children with disabilities.

\section{Keywords:}

\section{cooperation}

partnership

inclusion culture

tolerance 
Obecnie istnieje wiele aktów prawnych regulujących stosunki między rodziną a szkołą, niezależnie od tego, czy jest to placówka włączająca, integracyjna czy specjalna. Mają one zasięg zarówno krajowy, jak i globalny. Jednym z ważniejszych dokumentów sankcjonujących te relacje jest Konwencja o prawach dziecka. Zgodnie z jej zapisami każdemu przyznaje się prawo do nauki, umożliwia rozwój osobowości, gwarantuje prawa człowieka i podstawowe wolności. Dokument określa również prawa i obowiązki rodziców oraz gwarantuje pomoc przy ich realizowaniu.

Innym dokumentem o zasięgu europejskim regulującym prawa rodziców w relacji ze szkołą jest Europejska karta praw i obowiązków rodziców, zgodnie z którą mają oni m.in.:

$\rightarrow$ obowiązek angażowania się jako partnerzy w nauczanie ich dzieci w szkole,

$\rightarrow$ prawo dostępu do wszelkich informacji o instytucjach oświatowych, które mogą dotyczyć ich dzieci,

$\rightarrow$ prawo wpływania na politykę oświatową realizowaną w placówkach edukacyjnych, w których uczą się ich dzieci.

Zapisy dotyczące współpracy rodziców ze szkołą odnaleźć można także w Powszechnej deklaracji praw człowieka oraz europejskiej Konwencji o ochronie praw człowieka i podstawowych wolności. Dotyczą one m.in.:

$\rightarrow$ wyboru formy wychowania i rodzaju nauczania ich małoletnich dzieci,

$\rightarrow$ wyboru szkoły dla dziecka,

$\rightarrow$ wychowania dzieci zgodnie z wyznawanymi przekonaniami religijnymi ${ }^{1}$.

Nadrzędnym krajowym dokumentem uwzględniającym prawa rodziców jest Konstytucja Rzeczypospolitej Polskiej. Artykuł 70 stanowi, że "rodzice mają wolność wyboru dla swoich dzieci szkół innych niż publiczne. Oznacza to, że rodzice samodzielnie dokonują wyboru szkoły dla swojego dziecka, kierując się własnymi kryteriami wyboru". Największą rolę w tym zakresie odgrywa Ustawa o systemie oświaty

1 Powszechna deklaracja praw człowieka, bit.ly/11pBVFF [dostęp: 15.07.2019]; Konwencja o ochronie praw człowieka i podstawowych wolności, bit.ly/2xQBPvf [dostęp: 15.07.2019]. 
z 7 września 1991 r., która w pierwszym artykule zawiera zapisy o wspomaganiu przez szkołę wychowawczej roli rodziny. W dalszym brzmieniu uściśla obowiązki rodziców dotyczące spełniania obowiązku szkolnego przez dzieci, jak również działalność rad szkół i rad rodziców. Zgodnie z ustawą gremia te mają prawo do:

$\rightarrow$ uchwalania statutu szkoły lub placówki,

$\rightarrow$ przedstawiania wniosku w sprawie rocznego planu finansowego środków specjalnych szkoły lub placówki i opiniowania projektu planu finansowego,

$\rightarrow$ występowania do organu sprawującego nadzór pedagogiczny z wnioskami o zbadanie i dokonanie oceny działalności szkoły lub placówki, jej dyrektora lub nauczyciela,

$\rightarrow$ opiniowania planu pracy, projektu innowacji i eksperymentów pedagogicznych oraz innych spraw istotnych dla szkoły,

$\rightarrow$ oceniania $z$ własnej inicjatywy sytuacji oraz stanu placówki edukacyjnej i występowania z wnioskami do dyrektora, rady pedagogicznej, organu prowadzącego oraz do wojewódzkiej rady oświatowej, szczególnie w sprawach organizacji zajęć pozalekcyjnych i przedmiotów nadobowiązkowych,

$\rightarrow$ uchwalania w porozumieniu $z$ radą pedagogiczną:

a) programu wychowawczego, obejmującego wszystkie treści i działania o tym charakterze skierowane do uczniów,

b) programu profilaktyki dostosowanego do potrzeb rozwojowych uczniów oraz potrzeb danego środowiska, obejmującego wszystkie treści i działania o tym charakterze skierowane do uczniów, nauczycieli i rodziców,

$\rightarrow$ opiniowania programu i harmonogramu poprawy efektywności kształcenia lub wychowania².

Dla rodziców dzieci z niepełnosprawnością szczególne znaczenie mają te zapisy, które bezpośrednio wiążą się z edukacją osób ze specjalnymi potrzebami edukacyjnymi. Zaliczyć do nich należy ich prawo do uczestniczenia w spotkaniach zespołu nauczycieli i specjalistów, opracowującego indywidualny program edukacyjno-terapeutyczny dla danego ucznia. 
Na podstawie opracowanych ram prawnych współpracy można stworzyć zarys (nawet bardzo szczegółowy) dotyczący tego, czego powinno się od rodziców wymagać oraz czego oni mogą oczekiwać od szkoły, jej pracowników i całego systemu edukacji. Same zapisy ujęte w statucie placówki oświatowej, dotyczące organizacji i form współdziałania szkoły z rodzicami w zakresie nauczania, wychowania, opieki i profilaktyki, to wyczerpujący zestaw zagadnień związanych z rolą rodzica w szkole. Odnosi się wrażenie, że obowiązujące przepisy prawa bardzo wspierają (a także w pełni umożliwiają) podjęcie wspólnych działań rodziców i nauczycieli, którzy zmierzają do zwiększenia efektywności pracy szkoły. Jednak, jak pisze Bogusław Śliwerski, „W naszym kraju prawo jest po stronie rodziców, natomiast praktyka po stronie władz oświatowych i szkolnych" (Śliwerski 2016, s. 105). Niejednokrotnie rzeczywistość szkolna potwierdza taki stan rzeczy. Istnieje bowiem wiele luk w procedurach wdrażania prawa oświatowego oraz wiele słabych punktów w zakresie przestrzegania zasad demokratyzacji życia szkoły. Dotyczy to m.in. sztandarowego prawa rodzica do wyboru typu szkoły. Możliwość niezależnej i spójnej z własnymi przekonaniami decyzji bywa ograniczana przez czynniki wynikające z możliwości finansowych rodziców.

Status społeczny rodziny niekiedy obniża się ze względu na wiele wydatków związanych z niepełnosprawnością dziecka lub koniecznością zrezygnowania jednego z rodziców z pracy zawodowej. Zatem nawet jeśli rodzice wybiorą placówkę, która odpowiada ich oczekiwaniom, posłanie do niej dziecka jest często niemożliwe. Miejsce zamieszkania ucznia także bywa barierą w dostępie do wybranej placówki. W sytuacji, gdy szkoła zlokalizowana jest poza obwodem zamieszkania ucznia, ostateczną decyzję o przyjęciu do placówki podejmuje jej dyrektor, a nie rodzic. Mamy zatem tutaj również do czynienia z sytuacją, w której mimo zapisów prawa umożliwiających nieograniczony dostęp do edukacji uczniom z niepełnoprawnością, w praktyce nie da się ich wyegzekwować. Podobnie jest z umożliwieniem rodzicom uchwalania, w porozumieniu z radą pedagogiczną, programu wychowawczego szkoły i programu profilaktyki dostosowanego do potrzeb rozwojowych uczniów oraz potrzeb danego środowiska. Jeśli rada rodziców nie zgadza się z założeniami zawartymi w którymś z programów i w terminie 30 dni od dnia rozpoczęcia roku szkolnego nie podpisze takiego dokumentu, może tego dokonać dyrektor razem z organem 
sprawującym nadzór pedagogiczny. Nawet tak podstawowe zadanie szkoły, jakim jest wspomaganie wychowawczej funkcji rodziny i dostarczanie rodzicom informacji o postępach i trudnościach ucznia, nie jest w pełni realizowane. Wpływają na to zarówno pogłębiające się różnice wynikające z poglądów, przekonań i wartości między nauczycielami a rodzicami, jak i coraz częściej pojawiające się odmienne podejście obu grup do tematyki wychowania, rozumienia roli, celów oraz istoty placówki edukacyjnej i rodziny. Nie ułatwia tego także utrzymujący się od dawna brak kompetencji interpersonalnych i komunikacyjnych nauczycieli. Trudności z realizacją założeń prawa oświatowego potwierdza sprawozdanie Rzecznika Praw Obywatelskich z wykonania przez Polskę postanowień Konwencji, w którym odnajdujemy zapis: „Można zatem uznać, że ogólne ramy prawne pozwalają na realizację prawa osób z niepełnosprawnościami do edukacji. Wyzwaniem są jednak niektóre przepisy szczegółowe, które sprawiają, że choć prawo do edukacji może być realizowane, to nie istnieją odpowiednie rozwiązania prawne gwarantujące właściwą realizację dostępu do edukacji i egzekucję prawa"3.

Współpraca szkoły z rodzicami uczniów ze specjalnymi potrzebami edukacyjnymi wymaga zatem szerszych zobowiązań niż tylko realizacji zapisów prawnych. Kluczowe stają się działania na rzecz rozumienia znaczenia poszanowania prawa i wpływu uregulowań legislacyjnych na uspołecznienie środowiska szkolnego. W tym celu konieczna jest praca nad przemodelowaniem społecznej mentalności, nad zmianą ludzkich nastawień i eliminowaniem stereotypów. Wiąże się to zarówno z potrzebami i wyzwaniami czasu, jak i z koniecznością tworzenia coraz lepszych warunków realizacji procesu edukacyjnego. Obecnie zarówno rodzice, jak i szkoła mają świadomość, że wzajemnie się uzupełniają i czerpią korzyści ze wspólnych działań ${ }^{4}$. W edukacji włączającej, w której skuteczność przebiegu rewalidacji zależy szczególnie od współpracy obu podmiotów, wspólna praca na rzecz dobra dziecka staje się wręcz kluczowym zadaniem szkoły. O znaczeniu, formach i rodzajach tych działań powiedziano już chyba wszystko. Istnieje wiele praktycznych Polską w celu implementacji postanowień Konwencji o prawach osób niepełnosprawnych w latach 2015-2017. 
poradników dla nauczycieli, które zawierają wskazówki co do współpracy szkoły z rodzicami uczniów ze specjalnymi potrzebami edukacyjnymi ${ }^{5}$. Nie brakuje pozycji wydawniczych skierowanych do dyrektorów szkół, których treści dotyczą organizacji wspólnych działań wychowawców, specjalistów i nauczycieli z rodzicami uczniów z dysfunkcjami ${ }^{\text {. }}$. Również rodzice mogą skorzystać z publikacji poświęconych temu, jak wspólnie ze szkołą i kadrą pedagogiczną wspierać działania dla dobra dziecka. Nauczyciele także doceniają wagę wzajemnych pozytywnych relacji. Dlaczego zatem nadal słyszymy o trudnościach $w$ tym obszarze?

Jeśli uznamy, że szkoła to nie tylko instytucja, ale także miejsce tworzone przez ludzi, którzy wnoszą do niej swoje potrzeby i swój sposób widzenia świata, to na plan pierwszy wysuwa się kwestia relacji, kontaktów międzyludzkich oraz stworzenia atmosfery szacunku i życzliwości, poszanowania i akceptacji. W placówce realizującej edukację włączającą widać nieco wyraźniej, że grupa rodziców jest bardzo niejednorodna. Część z nich to osoby świadome, wymagające oraz darzące szkołę zaufaniem i wierzące w fachowość kadry edukacyjnej. Są one skłonne do zaangażowania - nie tylko wspomagania nauczycieli, ale także spierania się z nimi dla dobra dziecka. Część to rodzice niezainteresowani tym, co dzieje się w szkole. Posyłają do niej dzieci z niepełnosprawnością z nadzieją, że otrzymają tam one stosowną opiekę, wychowanie i nauczanie. Kolejna grupa to osoby z dodatkowymi trudnościami, które poza opieką nad dzieckiem z niepełnosprawnością doświadczają innych trudności życiowych, traktując niekiedy szkołę jako dodatkowy obowiązek lub oczekując od niej wsparcia posuniętego do granic wyręczania w tym, co tylko możliwe. Sami nauczyciele są również bardzo niejednorodnym środowiskiem, zróżnicowanym ze względu na: staż pracy, doświadczenia zawodowe, rodzaj placówki, w której pracują, system wartości i światopogląd czy przygotowanie do zawodu i roli wychowawcy w edukacji włączającej. Poszczególne grupy mają zatem różne oczekiwania względem samych siebie, osób, z którymi przyjdzie im współpracować, a także wobec idei edukacji włączającej i wizji współpracy. Bez postaw opartych na tolerancji i akceptacji nie da się rozwiązać ani nawet złagodzić żad[dostęp: 15.06.2019]. 
nego kryzysu wynikającego z występującego zróżnicowania. Problemów jest jednak dużo więcej i są one coraz trudniejsze.

Z tolerancją wiążą się nieodłącznie: wiedza, intelekt, odwaga, otwartość i doświadczenie. Ważna jest także umiejętność rozpoznawania własnego lęku oraz zdolność do konstruktywnego przetwarzania go w postawę sprzyjającą kontaktom z innymi. W relacjach z rodzicami dzieci z niepełnosprawnością istotna staje się umiejętność wyrażania uznania dla ich wiedzy i zaangażowania, życzliwość, cierpliwość, wyrozumiałość oraz dostrzeganie w każdym z nich ważnej osoby, a nie tylko anonimowego członka grupy. Wymaga to od nauczycieli wiedzy pedagogicznej i psychologicznej oraz wielu kompetencji interpersonalnych, szczególnie umiejętności inicjowania spotkań i prowadzenia rozmów na tematy trudne i bolesne. Niestety, kadra pedagogiczna często bagatelizuje te obszary, a braki w umiejętnościach interpersonalnych nie są dla niej źródłem dyskomfortu zawodowego. W ocenie rodziców nauczyciele nadal tworzą sporo barier komunikacyjnych. Bardzo często stawiają się w pozycji osoby dominującej i protekcjonalnie uświadamiającej rodzica (Żejmis, Jurga 2016).

W tym wymiarze szczególnego znaczenia nabierają pojęcia takie jak: współpraca, współdziałanie, partnerstwo. Mimo wielokrotnego odwoływania się do nich w relacjach szkoła - rodzic, nadal budzą kontrowersje i są powodem nieporozumień. Mieczysław Łobocki terminów tych używa zamiennie. Głównie uwypukla łączące je określenie samego celu „jako wspólnego działania rodziców i nauczycieli dla osiągnięcia dobra poszczególnych uczniów, klas, a nawet całej społeczności szkolnej w procesie nauczania i wychowania" (Łobocki 1985). Innymi słowy, współpraca i współdziałanie to przede wszystkim podejmowanie różnych zadań w imię wspólnie uzgodnionych celów. Zalicza się do nich także te działania, które wykonywane są tylko przez nauczycieli lub tylko przez rodziców, zgodnie z podjętą przez nich uprzednio decyzją w tej sprawie. Układ osób współdziałających jest taki, że jedni odgrywają rolę wiodącą, a drudzy, rozumiejąc konieczność takiej realizacji działań, włączają się w ten proces, niekoniecznie ze świadomością celów końcowych. Spełnienie powyższych oczekiwań bywa szczególnie trudne w kontekście współpracy szkoły z rodzicami uczniów ze specjalnymi potrzebami edukacyjnymi. W natłoku codziennych obowiązków związanych z niepełnosprawnością dzieci opiekunowie często nie mają przestrzeni na dodatkowe działania i dociekanie 
celów pracy nauczyciela. To właśnie brak zrozumienia motywów działania i zgubienie sensu zadań cząstkowych jest źródłem wielu nieporozumień. Ograniczenia aktywności rodziców uczniów ze specjalnymi potrzebami edukacyjnymi, wynikające z trudnej sytuacji życiowej, dodatkowo sprzyjają występowaniu napięć i nieporozumień. Szkoły muszą zatem wziąć pełną odpowiedzialność za kierowanie tym procesem, czyli za dokładne omówienie zasad współdziałania, określenie obowiązków obu stron i sposobu ich egzekwowania. Rzeczywistość jednak bywa nieco inna - często rodzice i przedstawiciele szkół nie wiedzą, jakie zadania mają wykonać w ramach wspólnych działań. Brakuje konkretnego programu pracy i uświadomienia własnych ograniczeń wynikających z podziału obowiązków.

Jeśli współpraca generuje problemy, to być może partnerstwo spełni oczekiwania zarówno rodziców, jak i nauczycieli. Zakłada ono osiąganie celu, ale w bardziej sformalizowanej formie, dopuszczającej istnienie względnej równości. Podstawą nawiązywania tego typu stosunków jest autentycznie odczuwana, nienarzucana z zewnątrz wola kontaktu z inną osobą. W myśl tej zasady nauczyciele oczekują od rodziców zaangażowania i pełnego zrozumienia ich działań, przy uwzględnienieniu równości ról. Zdaniem Jacka Kielina, oczekiwanie od rodziców partnerstwa jest jednak błędem (Kielin, Klimek-Markiewicz 2016). Nie będą oni nigdy dla terapeutów równorzędnymi partnerami w procesie leczenia, gdyż mimo wielkich chęci, gorącego serca i miłości, jaką darzą swoje dziecko, nie mają zawodowego przygotowania, specjalistycznej wiedzy i nie posiadają predyspozycji potrzebnych do pracy terapeutycznej. Stawianie w edukacji na partnerskie relacje to budowanie nierealnych oczekiwań, które nie są rozumiane i spełniane (Kielin 2012). Zmniejsza to jedynie wzajemne zaufanie i lojalność.

W złożonej sytuacji życiowej rodziców dzieci z niepełnosprawnościami lepszym rozwiązaniem jest udzielanie im szeroko rozumianej pomocy. W przestrzeni szkolnej odnosi się to do działań nauczycieli i specjalistów w kierunku pełnej odpowiedzialności za proces edukacyjny uczniów. Współuczestnictwo rodziców uznawane jest wówczas za możliwość, a nie konieczność. „Rodzice potrzebują pomocy i rady, żeby podtrzymać poczucie własnej kompetencji wychowawczej, przecież wychowując dziecko specjalnej troski, ponoszą oni porażki i niepowodzenia; postępy dziecka są powolne, trudno zauważalne, zachowanie nierzadko zaburzone. Rodzicom potrzebna jest nie tylko 
rada, ale również akceptacja i podtrzymanie ze strony nauczyciela - wychowawcy. Nie można zapominać o tym, że i nauczycielom potrzebne jest poczucie, że cieszą się szacunkiem i uznaniem" (Olechnowicz 1979).

Pomoc udzielana rodzicom dziecka z niepełnosprawnością musi być wieloaspektowa, wielowymiarowa. W szkole może ona być wyrażona poprzez wsparcie:

$\rightarrow$ emocjonalne (polegające na tworzeniu więzi atmosfery wzajemnego zaufania, akceptacji i troski), wyrażane przez komunikaty werbalne i niewerbalne,

$\rightarrow$ informacyjne, dotyczące udzielania porad, wskazówek niezbędnych do zrozumienia niepełnosprawności dziecka, istotna jest również wymiana doświadczeń, wspólnych spostrzeżeń,

$\rightarrow$ wartościujące, które polega na akceptacji, docenieniu potencjału rodzica (Kawczyńska-Butrym 1998).

Tak rozumiana pomoc umożliwia zarówno rodzicom, jak i nauczycielom wyeksponowanie kompetencji przynależnych do pełnionych przez nich funkcji. Za taką perspektywą przemawia wielokrotnie już przywoływany fakt, że organizowanie działań na rzecz wspólnego osiągania określonych efektów w kształceniu jest zbyt obciążające dla rodziców dzieci ze specjalnymi potrzebami edukacyjnymi. Oczekiwanie i wymaganie od nich zaangażowania paradoksalnie wywołuje skutki odwrotne do zamierzonych. Jest raczej przyczyną powstawania oporu niż zacieśniania współpracy. W takim podejściu upatruje się przyczyn niskiej efektywności roli rodziców w szkole, mimo wielu starań nauczycieli. W opinii tych pierwszych ważne są bardzo proste rozwiązania: „by mówić dobre, ale realne rzeczy, słuchać tego, co mają do powiedzenia, nie ukrywać niewiedzy w danym obszarze i otwarcie się do niej przyznać, zauważyć i docenić ich działania i postępy dziecka, szukać wsparcia innych osób, jeśli istnieje taka potrzeba" (Żejmis, Jurga 2016). Jak widać, są to oczekiwania odnoszące się do omawianego już aspektu relacji. Nie mogą być one w pełni realizowane bez zmian postaw, wartości, nastawień czy przekonań zarówno nauczycieli, jak i rodziców. Wymaga to od szkoły zagospodarowania przestrzeni związanej z kulturą włączania.

Truizmem jest stwierdzenie, że rodzina wraz ze szkołą uczą dzieci norm i zasad postępowania. Oczywiste jest także, że jakość umiejęt- 
ności, postaw i nawyków kształtowanych w tych środowiskach jest szczególnie ważna w wymiarze budowania relacji interpersonalnych. W procesie kształtowania podejścia do edukacji włączającej powyższe spostrzeżenie wydaje się jednak kluczowe, oznacza bowiem, że znaczenie ma, jakie postawy, poglądy i nastawienia przejawiają opiekunowie i wychowawcy. Istotne staje się to, czy mają oni pozytywne, otwarte poglądy na temat stosowania inkluzji w praktyce. A także czy są również świadomi tego, jak ważną rolę $w$ formowaniu postaw w całym środowisku szkolnym odgrywa przykład, który dają swoim postępowaniem.

Z raportu o wdrażaniu Konwencji o prawach osób niepełnosprawnych wynika ${ }^{7}$, że założenia formalne inkluzji są akceptowane i w większości szkół realizowane. Wiąże się to z działaniami na rzecz dostosowania programów nauczania, indywidualizacji metod i form pracy, wyborem odpowiednich pomocy dydaktycznych i sprzętu specjalistycznego, a także przygotowaniem infrastruktury szkolnej. Nadal jednak w szkołach ogólnodostępnych, do których uczęszczają uczniowie z niepełnosprawnością wybrzmiewają poglądy niekiedy sprzeczne z założeniami edukacji włączającej. Mimo upowszechnienia aktów prawnych o charakterze międzynarodowym (takich jak Powszechna deklaracja praw człowieka, Konwencja praw dziecka, Światowa deklaracja edukacji dla wszystkich, Deklaracja z Salamanki czy Międzynarodowa konwencja praw osób żyjących z niepełnosprawnością), wielu rodziców i nauczycieli obecność osób z niepełnosprawnością w systemie oświaty traktuje jedynie jako przywilej, a nie naturalny proces wynikający z przysługującego im prawa. Widoczne jest to wówczas, gdy rodzic zgłasza do dyrektora, że nie zgadza się, aby uczeń z niepełnosprawnością uczęszczał do klasy, w której uczy się jego sprawne dziecko. Duża część dyrektorów i nauczycieli zastanawia się, jakie kroki można podjąć, aby wyjść naprzeciw sugestii rodzica. W sytuacji odwrotnej, kiedy rodzic dziecka z niepełnosprawnością zgłosiłby brak zgody na uczestniczenie dziecka sprawnego w lekcjach, nikt nie potraktowałby tej sugestii poważnie. Żaden z dyrektorów nie podjąłby nawet dyskusji wokół tak postawionego problemu. Argument jest oczywisty. Każdy uczeń, jako obywatel, o prawach osób niepełnosprawnych oraz kierunki działań dotyczących przezwyciężania tych barier, bit.ly/2Fg3auU [dostęp: 17.06.2019]. 
ma prawo uczęszczania do szkoły powszechnej. Dlaczego zatem nie ma takiego myślenia, gdy chodzi o dzieci niepełnosprawne?

Dopóki w świadomości nauczycieli, dyrektorów i rodziców nie ugruntuje się przekonanie, że niepełnosprawność nikomu nie odbiera praw obywatelskich, dopóty będziemy mówić o mentalnym wykluczaniu i braku "ducha inkluzji" w szkołach. Tego rodzaju podejście kładzie się cieniem na wszystkie działania w szkole. Zmniejsza gotowość nauczycieli do poznawania innowacyjnych metod pracy, otwartość na nowe doświadczenia, ciekawość związaną ze sposobem funkcjonowania uczniów z niepełnosprawnością i zaangażowanie w ich życie rodzinne. Osobliwość wpływów szkoły w tym obszarze polega na tym, że jest ona zobligowana rozporządzeniami Ministra Edukacji Narodowej8 do udzielania pomocy psychologiczno-pedagogicznej nie tylko każdemu uczniowi, który tego potrzebuje, ale również jego rodzicom. Stwarza to wiele możliwości zadbania o sferę związaną z dialogiem społecznym i pracą w zakresie postaw oraz wartości istotnych z punktu widzenia omawianej problematyki.

Podsumowując, uznać można, że we współpracy szkoły z rodziną dominuje nastawienie na skuteczność i efekty. Każde działanie jest oceniane według rezultatów i czynności, które przynoszą określone korzyści edukacyjne. Coraz ważniejsze staje się wyznaczanie zadań i ich realizacja oraz wypełnienie zapisów prawa, a mniejsze znaczenie ma budowanie i utrzymywanie wzajemnych więzi. Jak na razie takie podejście nie prowadzi do sukcesu. Jest raczej źródłem dyskomfortu i zaniechania współpracy. Tworzy to nie tylko niesprzyjające środowisko kształcenia, ale także uniemożliwia formowanie odpowiednich postaw wobec nowych wyzwań edukacyjnych. Dlatego wydaje się zasadne, aby w budowaniu relacji między szkołą a rodzicami uczniów z niepełnosprawnością w większym stopniu zadbać o klimat wspólnej pracy, wzajemne zrozumienie i interakcje zachodzące między ludźmi. Rodzina z takim dzieckiem powinna być ujmowana systemowo, a dostarczane wsparcie powinno mieć charakter interdyscyplinarny, aby rodzice nie czuli się osamotnieni i bezradni ze względu na sytuację, w jakiej się znaleźli. rozporządzenie $w$ sprawie pomocy psychologiczno-pedagogicznej w publicznych przedszkolach, szkołach i placówkach (Dz.U. z 2017 r. poz. 1643). 
Zmiany w szkole można zacząć od małych kroków. Najważniejszym filarem tych zmian powinno być budowanie atmosfery wzajemnego zaufania oraz wspieranie, wspieranie i jeszcze raz wspieranie rodziców. W związku z tym warto zwrócić uwagę na rozwiązanie, które sprawdza się w wielu szkołach, czyli tzw. pokój rodzicielski. Służy on nie tylko do spotkań z rodzicami i budowania komfortowej atmosfery podczas rozmów, ale przede wszystkim sprawia, że mają oni poczucie swojego miejsce w szkole. Równie priorytetowe jest wypracowanie spójnych zasad organizowania takich spotkań. Ważny jest zarówno moment powitania rodzica, jak i zakończenia rozmów. Podanie ręki i odprowadzanie do drzwi to dość oczywisty sposób traktowania gościa (a w szkole tego typu gesty i zachowania nie są zbyt często spotykane).

Warto również pomyśleć o tym, by rodzice podczas dni otwartych mogli przemieszczać się bez kontroli nauczycieli po szkole i klasach, w których uczą się ich dzieci. Umożliwienie swobodnego oglądania dziecięcych prac, ciekawych projektów czy dokumentacji z życia klasy pozwoli rodzicom poczuć, że są mile widziani w placówce. Podobną funkcję może pełnić kącik dla rodziców - wydzielone miejsce (np. przy wejściu do klasy), w którym znajduje się tablica dla nich przeznaczona. Dzięki tej formie kontaktu mogą oni zapoznać się z interesującymi artykułami lub książkami opisującymi problematykę funkcjonowania dziecka, w tym także np. specyfikę wybranej niepełnosprawności.

W relacji nauczyciel - rodzic wiele zmienia formuła zajęć otwartych. Umożliwia ona obserwowanie dziecka (także z niepełnosprawnością) w czasie zajęć w gronie rówieśników. Weryfikacja umiejętności dzieci i zasobu ich wiadomości oraz indywidualnych problemów z tym związanych często uświadamia rodzicom trudności, z jakimi borykają się pedagodzy. Zdarza się, że sama gotowość nauczycieli do tak otwartego kontaktu budzi wśród rodziców szacunek i zaufanie. Zajęcia otwarte mogą mieć także charakter warsztatów, podczas których rodzice $z$ dziećmi realizują wspólny projekt (np. wykonanie kartek świątecznych, pisanek na zajęciach plastycznych). W klasie, do której uczęszcza uczeń z niepełnosprawnością, takie spotkanie jest doskonałą okazją do integrowania się i pogłębiania więzi emocjonalnej na różnych poziomach.

W grupie integracyjnej ważną rolę ogrywają spotkania z udziałem eksperta. Może to być osoba zaproponowana przez nauczyciela, gdy potrzebuje on wsparcia autorytetu, lub też specjalista, który od- 
powie na problemy rodziców. Pedagogizacja rodziców powinna jednak polegać nie tyle na teoretycznych wykładach, ile na dyskusji na konkretne tematy i wspólnym analizowaniu problemów wynikających z sytuacji życiowych. Niektóre z tematów można zaplanować z góry (np. na początku roku szkolnego), inne pojawiają się doraźnie - wynikają z aktualnych potrzeb i sytuacji w klasie. Istotne jest jednak systematyczne zasięganie opinii rodziców (np. z wykorzystaniem ankiet) na tematy dotyczące działalności szkoły/klasy i oczekiwań wobec placówki, nawet gdyby niemożliwe stało się ich zaspokojenie.

Ważną, choć mało rozpowszechnioną formą współpracy jest odwiedzanie przez nauczycieli domów swoich podopiecznych. Jest to zadanie trudne, ale w niektórych wypadkach konieczne. Szczególnie wówczas, gdy uczniowie sprawiają trudności i nauczyciele nie są w stanie zrozumieć podłoża zachowań dziecka. Wizyta domowa jest doskonałą okazją nie tylko do nawiązania życzliwej relacji, ale także do zasięgnięcia u źródła informacji dotyczących rozwoju dziecka, jego trybu życia, upodobań lub stanu zdrowia w celu pełniejszej diagnozy pedagogicznej i realnej oceny zakresu współpracy. W tym obszarze działań mieści się również bliższe poznanie rodziny dziecka w sytuacjach pozaszkolnych, w miejscach i okolicznościach neutralnych, takich jak: obóz rehabilitacyjny, wycieczka, ognisko czy impreza szkolna organizowana w czasie dogodnym dla rodziców.

Rozmowy telefoniczne oraz kontakt mailowy to standardowe formy komunikacji, zapomina się jednak o innych rozwiązaniach sprzyjających współpracy. Mogą to być listy, dyplomy, pisma pochwalne wysyłane do rodziców, które mogą sprzyjać zadowoleniu z osiągnięć dziecka. Często budzą dumę, podnoszą zaufanie do placówki i zwiększają zaangażowanie w życie szkoły - zarówno ucznia, jak i członków jego rodziny. Ogólną zasadą, którą należy się tu kierować, jest pozyskiwanie zaufania i życzliwości rodziców, czego raczej nie uda się osiągnąć, informując ich podczas spotkań jedynie o brakach i wadach ich dzieci.

Oprócz spotkań ogólnych warto pomyśleć także o niestandardowych formach komunikacji, takich jak wymiany informacji między trzema stronami: rodzicami, nauczycielami i uczniami. To rozwiązanie polega na rozmowie o sprawach dzieci w obecności głównych zainteresowanych stron. Stwarza okazję, by wszyscy uczestnicy mogli wyrabiać w sobie poczucie sprawstwa, uczyć się wspólnie rozwiązywać problemy i przejmować odpowiedzialność za cały proces edukacyjny. 
Trudno pominąć w działaniach na rzecz efektywnej współpracy ze szkołami organizowanie zewnętrznych grup wsparcia dla rodziców (bez udziału jej pracowników) oraz zachęcanie ich do tworzenia struktur formalnych, współdziałających z placówką (rada szkół, stowarzyszenie, fundacja). Doskonałą formą integrowania się grupy są także uroczystości szkolne - dla wielu osób jest to jeszcze jedna okazja do lepszego poznania dzieci i atmosfery panującej w placówce. Dla uczniów, szczególnie z niepełnosprawnością, tego typu wydarzenia są okazją do wykazania się posiadanymi zdolnościami i umiejętnościami. Wycieczki z kolei pozwalają na podejmowanie wspólnie z rodzicami decyzji i uwzględnianie indywidualnych możliwości psychofizycznych każdego ucznia. Dzięki takiej aktywności osoby z zewnątrz mogą dostrzec różnorodność wyzwań, przed którymi stoją nauczyciele, i docenić ich trud w realizowaniu potrzeb oświatowych wszystkich uczniów.

W edukacji grupy z niepełnosprawnością, częściej niż w przypadku uczniów sprawnych, wspólną przestrzenią działań rodziców i nauczycieli są prace domowe. W tej sytuacji konieczne jest, by pedagog był osobą decydującą od początku do końca o sposobie nauczania i uczenia się podopiecznego. Jeżeli dziecko nie będzie potrafiło się czegoś nauczyć, to do nauczyciela należy znalezienie sposobu na poradzenie sobie $z$ tą sytuacją, a rolą rodzica - jedynie wsparcie całego procesu. W tak rozumianym systemie nauczyciel wspomaga zarówno ucznia, jak i jego rodzica.

W niniejszym tekście nie udało się wymienić wszystkich możliwości współpracy szkoły z rodzicami uczniów z niepełnosprawnością, m.in. dlatego, że obszarów takiego współdziałania jest wiele. Zależą one nie tylko od specyfiki placówki edukacyjnej, ale i od potrzeb danej społeczności szkolnej. Warto jednak podkreślić, że to głównie od kompetencji nauczycieli i ich osobowości zależy, czy współpraca będzie dla rodziców procesem łatwym czy trudnym. Podsumowując, można zatem stwierdzić, że dobry nauczyciel może znaczyć więcej dla budowania współpracy, niż świetna organizacja czy najbardziej nawet dopracowany system edukacyjny. 